\title{
Enrichment and acclimation of an anaerobic mesophilic microorganism's inoculum for standardization of BMP assays
}

\author{
Ricardo Luis Radis Steinmetz ${ }^{\mathrm{a}, *}$, Melissa Paola Mezzari ${ }^{\mathrm{b}}$, Marcio Luis Busi da Silva ${ }^{\mathrm{a}}$, Airton Kunz ${ }^{\mathrm{a}, \mathrm{c}}$, \\ André Cestonaro do Amaral ${ }^{c}$, Deisi Cristina Tápparo ${ }^{c}$, Hugo Moreira Soares ${ }^{\mathrm{d}}$ \\ a Embrapa Suínos e Aves, BR 153 km 110, 89700-000 Concórdia, SC, Brazil \\ ${ }^{\mathrm{b}}$ Universidade do Oeste de Santa Catarina - UNOESC, 89560-000 Videira, SC, Brazil \\ ${ }^{\mathrm{c}}$ Universidade Estadual do Oeste do Paraná - UNIOESTE/CCET/PGEAGRI, 85819110, Cascavel, PR, Brazil \\ ' Universidade Federal de Santa Catarina - UFSC, Departamento de Engenharia Química, 88034001 Florianópolis, SC, Brazil
}

\section{H I G H L I G H T S}

- An appropriate inoculant is crucial for accurate BMP predictions.

- A method to develop mesophilic inoculum to attend VDI 4630.

- Biogas efficiency ranged from $89 \%$ to $99 \%$.

- Methanosarcinales was the dominant genus in the acclimated inoculum.

\section{A R T I C L E I N F O}

\section{Article history:}

Received 9 May 2016

Received in revised form 4 July 2016

Accepted 9 July 2016

Available online 9 July 2016

\section{Keywords:}

Anaerobic digestion

Biogas

Methanogens

VDI 4630

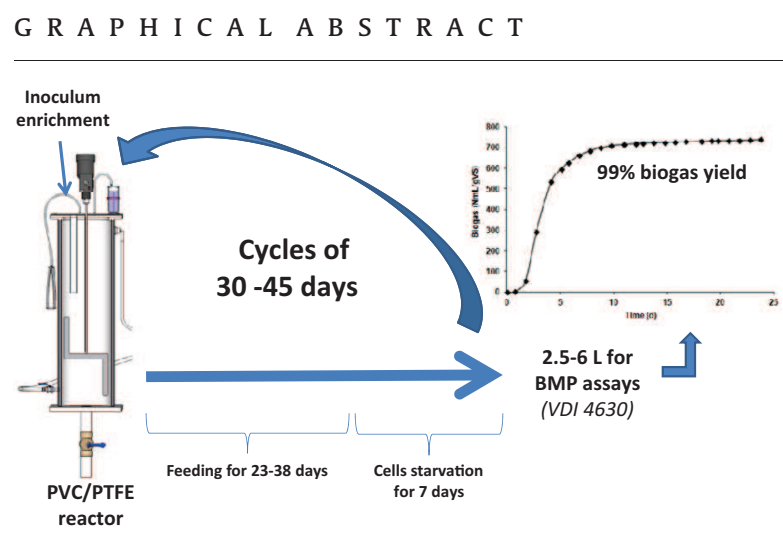

A B S T R A C T

Appropriate enrichment of anaerobic microorganism's consortium is crucial for accurate biochemical methane potential (BMP) assays. An alternative method to produce and maintain a mesophilic methanogenic inoculum was demonstrated. Three sources of inoculum were mixed and acclimated for 857 days in order to reach steady conditions $(\mathrm{pH}=7.90 \pm 0.46 ; \quad \mathrm{VS} / \mathrm{TS}>50 \%$; VFA/alkalinity $=0.16 \pm$ $0.04 \mathrm{~g}_{\text {Acetic Acid }}\left(\mathrm{g}_{\mathrm{CaCO}_{3}}\right)$. Biogas yield $>80 \%$ was obtained after 70 days of inoculum acclimation in comparison to standard cellulose ( $\left.>600 \mathrm{~mL}_{\mathrm{N}} / \mathrm{g}_{\mathrm{vS}}\right)$. Methanogen community analysis based on 16S rDNA of the inoculum revealed Archaea concentration of $3 \times 10^{12}$ gene copies/g (Methanobacteriales $8 \times 10^{10}$; Methanomicrobiales $8 \times 10^{10}$; and Methanosarcinales $4 \times 10^{11}$ gene copies/g). The proposed method for development and maintenance of microorganism enrichment inoculum demonstrates consistent BMP data which is a requirement for dependable prediction of biogas production at field scale operations.

(c) 2016 Elsevier Ltd. All rights reserved.

\section{Introduction}

In an attempt to decrease dependency on fossil fuels, different sources of renewable feedstocks has been considered to

\footnotetext{
* Corresponding author at: EMBRAPA, P.O. Box 321, 89700-000 Concórdia, SC, Brazil.

E-mail address: ricardo.steinmetz@embrapa.br (R.L.R. Steinmetz), .
}

alternatively supply the world increasing energy demands. In this scenario, production of biofuel methane from livestock byproducts, agricultural industry wastes and agricultural feedstocks biomass are receiving special attention worldwide. Two parameters are critical for determination of intrinsic economic value of biomethane production. One is the biochemical methane potential (BMP) of the feedstock supply and the other is the availability capacity of the substrate (Deublein and Steinhauser, 2010). Reports on 
kinetic of methane production from different biomasses are scarce in the literature. Therefore, more studies are needed to encompass a more comprehensive range of feedstock to expand current BMP inventory data. Besides variations in substrates it is also important to take into account climate and other intrinsic characteristic of each particular region in order to avoid data misreading.

Protocols for anaerobic digestion and BMP estimation are available (Angelidaki et al., 2009; Labatut et al., 2011). Briefly, BMP is obtained using a small amount of substrate sample incubated in mesophilic conditions and in the presence of an anaerobic microorganism's inoculum. The cumulative gas produced over time is then measured until it reaches steady state. In general, these experiments are performed in laboratory batch reactors, and the specific BMP is expressed as volume of biogas or methane per unit of mass of the organic matter (tests conducted under specific temperature and pressure conditions). Some standard methods for BMP assays are available such as DIN 38414-8 (1985), ISO 11734 (1995), ASTM E2170-01 (2001) and VDI 4630 (2006).

Not surprisingly, BMP data accuracy is highly dependent on the specific metabolic capabilities of the inoculum used. Furthermore, reduced methanogenic activity from microorganism consortium can ultimately lead to poor reproducible results and underestimation of biogas yield (Angelidaki et al., 2009; Bauer et al., 2008). Angelidaki et al. (2009) suggest the use of a fresh inoculum obtained from an active anaerobic reactor, i.e. manure biogas plants or upflow anaerobic sludge blankets (UASB) treating domestic wastewaters. Microorganisms obtained from these potential inoculum sources are then pre-incubated for 2-5 days prior to BMP assays in order to deplete any residual biodegradable organic material. Gu et al. (2014) found association between inoculum source and acclimation process in the biodegradability potential of cellulosic substrates. In addition to inoculum sources and acclimation processes two other factors are also likely to interfere with the biodegradation potential. De Vrieze et al. (2015) identified differences in substrate degradation efficiency depending on methanogenic communities' structure present in the inoculum. Some BMP methods are based on the use of inoculum source obtained from mesophilic digesters (DIN 38414-8, 1985; ISO 11734, 1995; VDI 4630, 2006). The method VDI 4630 (2006) emphasizes the use of inoculum from digesters operating under co-digestion of substrates from agricultural sources. Therefore, variations among inoculum source and methods of enrichment and acclimation needs to be standardized (DIN, 1985; VDI, 2006; Chen et al., 2008) to allow dependable data comparison and validation.

BMP standard methods are usually based on the use of inoculum source obtained from up-scale biodigesters (DIN, 1985; ISO, 1995; ASTM International, 2001; VDI, 2006). The methods DIN 38414-8 (1985) suggest the use of a 'reference sludge' from municipal sewage treatment plant, without inhibitors, maintained biologically active by regular addition of small amounts of raw sludge. The method ASTM E2170-01 (2001) define the inoculum as 'digester sludge', such reactor are generally operated at $35^{\circ} \mathrm{C}$ with a typical retention time of 25-30 days and receiving predominantly domestic wastewater. This definition is quite similar to described in ISO 11734 (1995). Both methods recommend incubation for 5-10 days before BMP test to reduce biomass and odor problems and to improve the dewatering of sludge. ASTM include recommendation to sieve in 2-mm mesh screen to remove large particles. The only method focused in agricultural substrates (e.g., energy crops) is the method VDI 4630 (2006) with emphasizes the use of inoculum from digesters operating under co-digestion of substrates from agricultural sources in mesophilic conditions $\left(37^{\circ} \mathrm{C}\right)$. The VDI recommend use inoculum from up-scale plant pre-acclimated to the sample substrate that will be evaluate in the BMP assay, situation easy to find in countries that the anaerobic digestion technology is strong (e.g. Germany, Italy or USA). Unfortunately, many regions around the globe interested in the implementation of biogas technology do not have prompt access to these inoculum sources. Therefore, variations between inoculum source and methods of enrichment and acclimation needs to be standardized (Angelidaki et al., 2009; Chen et al., 2008; VDI, 2006) to allow dependable data comparison and validation.

Therefore, the objective of this work was to design and evaluate an alternative method for enrichment and acclimation of an anaerobic microorganism inoculum for reliable BMP assay. The data obtained herein was compared to other BMP data inventory accessible from independent laboratories for validation.

\section{Material and methods}

\subsection{Inoculum sources}

The inoculum used in this work was prepared by mixing equal volumes of anaerobic sludge from two independent UASB reactors and fresh dairy cattle manure. Anaerobic sludge was obtained from a field scale UASB reactor (not operating under mesophilic conditions) fed swine wastewater at EMBRAPA swine wastewater treatment facilities (Inoculum A) (Kunz et al., 2009). Fresh dairy cattle manure was obtained from a local farm (Inoculum B). Cattle manure contained some undigested grass leaves and small stones that are ingested by animals or accidently collected at the time of sampling. Thus, to minimize eventual operational mixing in the reactor, these samples were carefully filtered out prior to reactor inoculation. Anaerobic mesophilic $\left(38-42^{\circ} \mathrm{C}\right)$ granular sludge was obtained from an UASB treating effluents from a gelatin manufactory (Inoculum C). Fresh aliquots from inoculum A and B were collected and immediately added to the stock microorganism's culture reactor one day prior to inoculum mixture. Fresh inoculum C were collected only every 6-8 months and kept in $20 \mathrm{~L}$ polyethylene vessel, at room temperature $\left(\sim 20^{\circ} \mathrm{C}\right)$ and under water seal to minimize oxygen intrusion. Aliquots of stored inoculum $\mathrm{C}$ were added into stock reactor every cycle of 30-40 days.

\subsection{Inoculum acclimation}

During the first 70 days of acclimation, $6 \mathrm{~L}$ of inoculum from sources $\mathrm{A}, \mathrm{B}$ and $\mathrm{C}$ were mixed and stored in a $20 \mathrm{~L}$ polyethylene vessel kept at $37 \pm 3{ }^{\circ} \mathrm{C}$ in a thermostatic water bath (MB-5, Julabo, Germany). On day 70 , the inoculum mixture was transferred into a new $40 \mathrm{~L} \mathrm{PVC/PTFE} \mathrm{reactor} \mathrm{as} \mathrm{depicted} \mathrm{in} \mathrm{Fig.} \mathrm{1.} \mathrm{The} \mathrm{reactor} \mathrm{was}$ designed with two concentric PVC tubes (both with $88 \mathrm{~cm}$ length; 24 and $27 \mathrm{~cm}$ internal diameter, respectively) closed at both ends with PTFE holders. Inoculum feeding (as described in Section 2.3) was performed through the $2 \mathrm{~cm}$ diameter tube installed at the top holder. The metal rod (Fig. 1) was surrounded by a $1 \mathrm{~cm}$ diameter tube to avoid contact with the enrichment. Two holes of $0.7 \mathrm{~cm}$ internal diameter each was used to release built up pressure. Gas lines were made of Tygon ${ }^{\circledR}$ tubes $(1 \mathrm{~cm}$ i.d.) placed inside a $10 \mathrm{~mm}$ water column seal to avoid air intrusion and possible gas dilutions. The inoculum was continuously mixed (40-60 rpm; up to $20 \mathrm{~N} / \mathrm{m}^{2}$ ) using a shaved steel helix coupled to a rotor (RW 20 digital, IKA/China). At the bottom of the reactor, a PVC tube (3.5 $\mathrm{cm}$ i.d.) containing a stainless steel ball valve was installed for samplings. The reactor's jacket wall was pumped with water $\left(37 \pm 1{ }^{\circ} \mathrm{C}\right.$; external thermostatic water bath; MB-5, Julabo, Germany) to stimulate mesophilic conditions.

\subsection{Inoculum enrichment and maintenance}

After 70 days of acclimation the enriched inoculum was sieved (ø $2 \mathrm{~mm}$ ) and then transferred to a new $40 \mathrm{~L}$ reactor made of PVC/ 


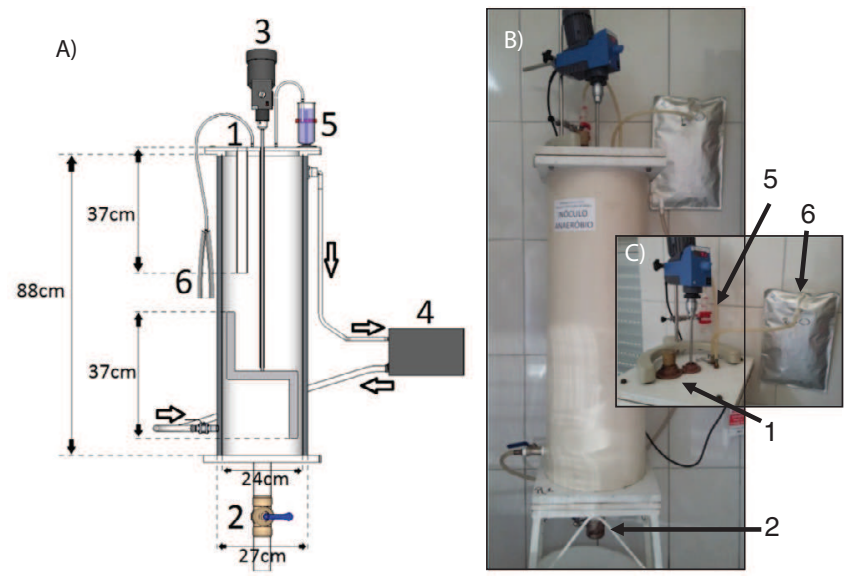

Fig. 1. PVC/PTFE reactor used for enrichment and acclimation of a mesophilic inoculum for BMP assays. Bioreactor's schematic (A); Picture (B); and close detail of its top end (C). Feeding tube, (1), valve (2), mixing system (3), external water bath (4), water column seal (5), and gas-tight sampling bag (6).

PTFE. Three liters of fresh inoculum from sources A, B and C were added into the filtered inoculum and diluted with distilled water up to $40 \mathrm{~L}$ total volume. The reactor was kept under continuous agitation under mesophilic conditions. For the first 4 weeks, a substrate blend composed of proteins, carbohydrates and lipids was fed daily into the reactor at loading rate of $0.3 \mathrm{~g}_{\mathrm{vs}}(\mathrm{L} \cdot \mathrm{d})^{-1}$. This supplemental substrate was prepared with $30 \%$ of VS from grass (dried at $60^{\circ} \mathrm{C}$ in air circulating oven then grounded to particle size of less than $1 \mathrm{~mm}$ ) to serve as source of cellulose, lignin and chlorophyll; $30 \%$ of VS from feedstuff for pigs in lactation phase (based on corn and soybean meal without addition of preservatives, pre-mix or antibiotics/fungicides); $25 \%$ of VS from powdered milk as source of lactose, amino acids, lipids and some micronutrients. Lastly, sunflower oil was added (15\% VS content) to supply the enrichment with lipid substrate. The prepared substrate cocktail was suspended in $100 \mathrm{~mL}$ of water prior to feeding reactor.

After four weeks of acclimation, feeding was interrupted for 7 days to reduce production of background biogas that could potentially interfere with BMP assays. For the BMP assays, 2.5-6 $\mathrm{L}$ of the acclimated inoculum was used. The same amount of volume removed from the stock inoculum reactor was replenished with fresh aliquots from sources $\mathrm{A}, \mathrm{B}$ and $\mathrm{C}$ following the same acclimation period and feeding procedure.

\subsection{BMP assays}

BMP assays were conducted according to VDI 4630 (2006). Batch experiments were performed in $250 \mathrm{~mL}$ glass reactors connected to $500 \mathrm{~mL}$ glass eudiometers. The reactors were prepared with 180-200 $\mathrm{g}$ ( 4-5 gVS) of the acclimated inoculum and 1-2 $\mathrm{g}$ $\left(\sim 1-1.5 \mathrm{gVS}\right.$; depending on ratio: $\left.\mathrm{VS}_{\text {sample }} / \mathrm{VS}_{\text {inoculum }} \leqslant 0.5\right)$ of carbon as substrate. The reactors were then sealed and stored at $37^{\circ} \mathrm{C}$ until the establishment of stationary daily gas production rate ( $<1 \%$ of the total amount produced). The production of gas was quantified on a daily basis by displacement of the sealant liquid level (DIN 38414-8, 1985) in the eudiometers. The dried biogas volume was determined by subtracting the water vapor content based in the water vapor pressure, according to VDI recommendations. The dried biogas volume was then normalized to standard temperature and pressure i.e., $273 \mathrm{~K}$ and $1013 \mathrm{hPa}$, respectively. BMP was estimated as the total biogas produced divided by the respective sample VS content. The results were normalized to the total biogas produced from negative controls prepared with inoculum only. BMP assays were performed in triplicate.

\subsection{Specific methanogenic activity}

For the specific methanogenic activity, the inoculum samples were diluted to $10 \mathrm{gTS} / \mathrm{L}$ using nutrient-buffer solution as described in ISO 11734 (1995). The test was conducted in an Automatic Methane Potential System II (Bioprocess Control, Sweden), with $400 \mathrm{~mL}$ of inoculum $\left(37^{\circ} \mathrm{C}\right)$ to reduce biogas production baseline. After stability, $1 \mathrm{~g} / \mathrm{L}$ acetate solution or cellulose solution was spiked. The data evaluation was conducted according to Hussain and Dubey (2015). All tests were performed in triplicate.

\subsection{Physical-chemical analyses}

Biogas was collected from eudiometers using gas-tight bag samplers (plastic/aluminum foil, Hermann Nawrot AG, Germany) and analyzed by portable infra-red analyzer BIOGAS5000 (Landtec, USA).

Once a week a total of $150 \mathrm{~mL}$ of each inoculum sample was taken from the reactors and analyzed for $\mathrm{pH}$, total solids (TS) and volatile solids (VS) contents (APHA et al., 2012). The correlation between volatile fatty acids (VFA) and alkalinity (ALK) was determined by centrifugation of $50 \mathrm{~mL}(3493 \times \mathrm{g}$ for $10 \mathrm{~min})$ followed by titration according to Buchauer (1998).

For granulometry distribution, $1 \mathrm{~L}$ sample was filtered through sequential sieves $(\varnothing=2,1.2$ and $0.5 \mathrm{~mm})$. The particles retained on the sieve were gently washed with distilled water. After standing $5 \mathrm{~min}$ to remove excess water the sieves were weighed. Granulometry was estimated by the mass of material retained on each sieve in comparison with all sediment retained on total sieve set.

\subsection{Evaluation of digestion efficiency}

Microcrystalline cellulose ( $20 \mu$ size, Sigma-Aldrich) was used as internal standard for the evaluation of digestion efficiency according to VDI 4630 recommendations (VDI, 2006). Biogas yield and BMP were measured from 23 different experimental assays prepared with same inoculum obtained at different acclimation times ranging from 10 to 857 days (Table 1 ). Inoculum perfor-

Table 1

Summary of the experimental assays used to determine the effects of inoculum acclimation period on specific biogas yield and BMP.

\begin{tabular}{llll}
\hline Assays & Acclimation time (d) & Inoculum storage & Acclimation process \\
\hline 1 & 10 & 20-L polyethylene vessel & Mixture and stored \\
2 & 10 & 20-L polyethylene vessel & Mixture and stored \\
3 & 10 & 20-L polyethylene vessel & Mixture and stored \\
4 & 70 & PVC/PTFE reactor & Cycles of 45 days \\
$5-7$ & $71-252$ & PVC/PTFE reactor & Cycles of 45 days \\
$8-13$ & $253-570$ & PVC/PTFE reactor & Cycles of 45 days \\
$14-23$ & $571-875$ & PVC/PTFE reactor & Sieved $(2 \mathrm{~mm})$ \\
Cycles of 30 days & Sieved $(2 \mathrm{~mm}) ; \mathrm{dV} \sim 2.5 \mathrm{~L}$ \\
\hline
\end{tabular}


mance was determined after 10 days of inoculation (Steinmetz et al., 2014) using the inoculum in natura (assay 1); filtered ( $2 \mathrm{~mm}$ sieve; assay 2); or diluted $10 \% \mathrm{w} / \mathrm{v}$ (assay 3 ) in buffermicronutrient solution according ISO 11734 (1995). Assay 4 was prepared with inoculum from the PVC/PTFE reactor (as described in section 2.3 above) after 70 days of acclimation. Assays 5 to 23 were prepared using inoculum from the PVC/PTFE reactor collected at different acclimation times from 71 to 252 days. In assay 8 and subsequent tests, the inoculum was previously filtered using $1 \mathrm{~mm}$ diameter sieve. Nitrogen was used to purge the $250 \mathrm{~mL}$ glass reactors before BMP incubation. Assays were also conducted to determine the effects of stock culture re-inoculation after 30 or 45 days on BMP.

The efficiency of the proposed method of inoculum enrichment and acclimation was determined by comparison of the BMP results with data collected from independent laboratories (anaerobic digestion interlaboratory comparison databank) (Steinmetz et al., 2015) using different inoculum enrichment strategies and acclimation times. All tests used identical subsamples concentrations from the interlaboratory study of the substrates microcrystalline cellulose, gelatin, poultry litter (14\% protein, $16 \%$ fiber, < $1 \%$ oil, $13 \%$ ashes and $75 \% \mathrm{VS}$ ) and dried sludge from wastewater treatment (10\% protein, $<1 \%$ fiber, $<1 \%$ oil, $18 \%$ ashes and $64 \%$ VS).

\subsection{DNA extraction and $q P C R$ analysis}

Genomic DNA was extracted from inoculum sources A, B and C (250 mg each) using a PowerSoil DNA Isolation kit (Mo Bio Laboratories Inc.) according to manufacturer's instructions. Gene copies concentration of total Archaea (ARC and the dominant methanogenic orders from biodigesters - Methanosarcinales (MSL), Methanobacteriales (MBT) and Methanomicrobiales (MMB) (Song et al., 2010), were estimated by real-time quantitative PCR (qPCR) analysis with primers and probe sets described in Table 2 . Standard curves were prepared by serial dilutions $\left(10^{10}\right.$ to $10^{3}$ gene copies $\mu \mathrm{L}^{-1}$ ) of recombinant plasmid DNA containing cloned target sequences as previously described (Mezzari et al., 2013) and amplified using the QuantStudioTM 6 Flex Real-Time PCR System (Applied Biosystems ${ }^{\circledR}$ ). All primer sets were suitable for SYBR green application, except for the family MMB, due to crossreacting potential to other non-targeted methanogenic groups (Reitschuler et al., 2014). SYBR reaction mixtures were performed using the QuantiFast ${ }^{\circledR}$ SYBR $^{\circledR}$ Green PCR Kit (Qiagen), and Taqman probe reactions used the GoTaq ${ }^{\circledR}$ Probe PCR System Kit (Promega). PCR reaction mix was performed according to the manufacturer's protocols with final concentration of primers at $250 \eta \mathrm{M}$ and probe at $125 \eta \mathrm{M}$. Amplification was performed in a two-step thermal cycling condition (QuantStudioTM 6 Flex Real-Time PCR System, Applied Biosystems ${ }^{\circledR}$ ) for both SYBR $\left(5 \mathrm{~min}\right.$ at $95^{\circ} \mathrm{C}$ followed by 40 cycles of $10 \mathrm{~s}$ at $95^{\circ} \mathrm{C}$ and $30 \mathrm{~s}$ at $\left.60^{\circ} \mathrm{C}\right)$ and Taqman $(2 \mathrm{~min}$ at $95{ }^{\circ} \mathrm{C}$ followed by 40 cycles of $15 \mathrm{~s}$ at $95^{\circ} \mathrm{C}$ and $1 \mathrm{~min}$ at $55^{\circ} \mathrm{C}$ ). All cDNA templates were analyzed in triplicates.

\subsection{Statistical analysis}

Data were presented as average \pm standard deviation (SD) from triplicate. Statistical differences between data sets were verified by ANOVA at $p<0.05$.

\section{Results and discussion}

The development and maintenance of an active inoculum in laboratory scale conditions can reduce parameters variations typically associated with differences in inoculum sources and environmental conditions. These variations are most likely to interfere with BMP data accuracy and consistency. To the best of the authors knowledge, only one study has focused on storage of inoculum under laboratory conditions for anaerobic digester start up (Li et al., 2014). However, the inoculum was conditioned under thermophilic and not mesophilic conditions in which BMP methods are based on. Moreover, physical-chemical characteristics of the different substrate sources of each source of inoculum were not presented, which makes it difficult to replicate.

The physical-chemical characteristics of different sources of inoculum use in this work are shown in Table 3. The method of titration to estimate the VFA/ALK ratio was used to infer on organic acids (e.g. acetic) accumulation or depletion of alkalinity prior to $\mathrm{pH}$ decrease. Acid accumulation is frequently observed when overloading reactors (Lili et al., 2011) leading to increased food/ microorganisms ratio. The UASB which provided inoculum A, had a recurrent operational problem in solid-liquid separation resulting in increased loading of solids into the digester and constant discharge of sludge. Microorganism's biomass was concomitantly discharged in the process whereas the concentration of influent carbon substrate from swine manure remained constant. This expected increase in food/microorganism ratio most likely contributed to the higher VFA/ALK as observed in inoculum A. Controlling solid-liquid separation can be very challenging at field scale operations. It should be noted that the low solid contents present in inoculum A could enhance TS dilution to within $40 \mathrm{~g} / \mathrm{L}$. In fact, this sample physical-chemical characteristics are very representative to many field scale UASB treating swine wastewaters.

Sample from dairy cattle manure (inoculum from source B) contributed to $>90 \mathrm{~g} / \mathrm{kg}$ VS (average of $122.4 \mathrm{~g} / \mathrm{kg}$ ) and $78.7 \% \mathrm{VS} / \mathrm{TS}$. This inoculum provided great buffer capacity within $\mathrm{pH}$ $6.60 \pm 0.37$. On the contrary, the other two sources of inoculum (A and C) showed a much higher $\mathrm{pH}(7.96 \pm 0.19$ for source $\mathrm{A}$ and $7.93 \pm 0.53$ for source $C$ ). These results indicate that inoculum from source B can be used to improve the biodegradation of slightly acidic substrates such as fibers and cellulose that are typical substrates encountered in agricultural feedstocks.

The inoculum $C$ was the only one obtained from mesophilic condition. A preliminary analysis of granulometry distribution indicated that $>50 \%(\mathrm{w} / \mathrm{w})$ of the granules in sludge was above

Table 2

Real-time quantitative PCR primer and probe sequences and fragment sizes.

\begin{tabular}{|c|c|c|c|c|}
\hline Target & Primers/ Probes & Function & Sequence $\left(5^{\prime}-3^{\prime}\right)$ & Size (bp) \\
\hline Archaea & $\begin{array}{l}\text { ARC787 } \\
\text { ARC1059 }\end{array}$ & $\begin{array}{l}\text { Forward } \\
\text { Reverse }\end{array}$ & $\begin{array}{l}\text { ATTAGATACCCSBGTAGTCC } \\
\text { GCCATGCACCWCCTCT }\end{array}$ & 273 \\
\hline Methanobacteriales & $\begin{array}{l}\text { MBT857 } \\
\text { MBT1196 }\end{array}$ & $\begin{array}{l}\text { Forward } \\
\text { Reverse }\end{array}$ & $\begin{array}{l}\text { CGWAGGGAAGCTGTTAAGT } \\
\text { TACCGTCGTCCACTCCTT }\end{array}$ & 343 \\
\hline Methanosarcinales & $\begin{array}{l}\text { MSL812 } \\
\text { MSL1159 }\end{array}$ & $\begin{array}{l}\text { Forward } \\
\text { Reverse }\end{array}$ & $\begin{array}{l}\text { GTAAACGATRYTCGCTAGGT } \\
\text { GGTCCCCACAGWGTACC }\end{array}$ & 354 \\
\hline Methanomicrobiales & $\begin{array}{l}\text { MMB749 } \\
\text { MMB282 } \\
\text { MMB832 }\end{array}$ & $\begin{array}{l}\text { Taqman } \\
\text { Forward } \\
\text { Reverse }\end{array}$ & $\begin{array}{l}\text { TYCGACAGTGAGGRACGAAAGCTG } \\
\text { ATCGRTACGGGTTGTGGG } \\
\text { CACCTAACGCRCATHGTTTAC }\end{array}$ & 506 \\
\hline
\end{tabular}


Table 3

Physical-chemical and biological characteristics of different sources of inoculum utilized in this work.

\begin{tabular}{|c|c|c|c|c|}
\hline Inoculum & A & B & C & Laboratory \\
\hline Source & $\begin{array}{l}\text { UASB sludge from swine manure } \\
\text { treatment }\end{array}$ & $\begin{array}{l}\text { Fresh cattle } \\
\text { manure }\end{array}$ & $\begin{array}{l}\text { UASB sludge from gelatin } \\
\text { manufactory }\end{array}$ & $\begin{array}{l}\text { Mixture of A, B and } \\
\text { C }\end{array}$ \\
\hline $\mathrm{T}\left({ }^{\circ} \mathrm{C}\right)$ & 25 & 25 & $38-42$ & 37 \\
\hline $\mathrm{pH}$ & $7.96(0.19)$ & $6.60(0.37)$ & $7.93(0.53)$ & $7.20-8.80$ \\
\hline VFA/ALK (g $\left.g_{\text {Acetic Acid }} / g_{\mathrm{CaCO}_{3}}\right)$ & $0.48(0.23)$ & $\mathrm{NA}$ & $0.12(0.02)$ & $0.10-0.35$ \\
\hline TS $(\mathrm{g} / \mathrm{kg})$ & $20.1(5.9)$ & $155.1(23.8)$ & $64.4(14.9)$ & $29.9-59.1$ \\
\hline VS g/kg & $11.4(4.4)$ & $122.4(22.6)$ & $40.9(7.3)$ & $19.2-40.4$ \\
\hline $\mathrm{VS} / \mathrm{TS} \%(\mathrm{w} / \mathrm{w})$ & 56.7 & 78.9 & 63.5 & $51.3-69.9$ \\
\hline ARC (gene copies/g) & $6.2(4.1) \times 10^{11}$ & $1.4(1.0) \times 10^{10}$ & $1.4(1.6) \times 10^{12}$ & $3.3(0.1) \times 10^{12}$ \\
\hline MBT (gene copies/g) & $5.9(1.6) \times 10^{10}$ & $4.4(3.0) \times 10^{10}$ & $5.7(1.6) \times 10^{10}$ & $7.7(0.8) \times 10^{10}$ \\
\hline MMB (gene copies/g) & $5.3(4.0) \times 10^{9}$ & $5.7(1.7) \times 10^{7}$ & $3.0(1.4) \times 10^{10}$ & $7.7(0.4) \times 10^{10}$ \\
\hline MSL (gene copies/g) & $5.5(3.3) \times 10^{10}$ & $1.7(1.3) \times 10^{8}$ & $1.4(1.6) \times 10^{11}$ & $4.2(2.0) \times 10^{11}$ \\
\hline $\begin{array}{l}\text { Methanogenic activity acetate }\left[\mathrm{g} \mathrm{CH}_{4}-\mathrm{DQO} /(\mathrm{g}\right. \\
\text { VSS d })]\end{array}$ & $0.050(0.003)$ & $0.049(0.002)$ & $\begin{array}{l}0.326(0.029)^{*} \\
0.176(0.007)^{* *}\end{array}$ & $0.184(0.003)$ \\
\hline $\begin{array}{l}\text { Methanogenic activity cellulose }\left[\mathrm{g} \mathrm{CH}_{4}-\mathrm{DQO} /(\mathrm{g}\right. \\
\text { VSS } \mathrm{d})]\end{array}$ & $0.013(0.002)$ & $0.028(0.003)$ & $\begin{array}{l}0.020(0.001)^{*} \\
0.014(0.003)^{* *}\end{array}$ & $0.047(0.004)$ \\
\hline
\end{tabular}

Average (standard deviation); NA: Not analyzed (impractical to extract liquid fraction by centrifugation); ARC: Total Archaea; MBT: Methanobacteriales; MMB: Methanomicrobiales, and MSL: Methanosarcinales.

* Fresh inoculum.

** Old inoculum ( $>6$ months stored at room temperature).

$1.2 \mathrm{~mm}$. According to literature (Angelidaki et al., 2009; De Vrieze et al., 2015) this is a prerequisite parameter for successful BMP tests. According to Angelidaki et al. (2009), the amount of VS (or VSS) present in sludge can be correlated to microorganism's concentration. The VDI method recommends a minimum of $50 \% \mathrm{VS} /$ TS to ensure satisfactory quantity of microorganism for BMP assays. The low VS/TS measured initially in inoculum $\mathrm{C}$ was later adjusted after discriminatory evaluation of the solid content in the UASB sludge blanket column. Inoculum with VS/TS above $50 \%(\mathrm{w} / \mathrm{w})$ were used for re-inoculation of PVC/PTFE reactor only after 322 days on experimental time frame. These changes in VS/ TS are clearly demonstrated in Fig. 2a where ratios above 60\% $(\mathrm{w} / \mathrm{w})$ were achieved after 405 days.

Fig. 2 shows variations in $\mathrm{pH}$ and VFA/ALK over time between 70 and 857 days. VFA/ALK ratio is typically used to infer on accumulation of organic acids (e.g. acetic) or alkalinity depletion before a pH decrease. According to Lili et al. (2011), the VFA/ALK ratio also served to indicate organic load. Thus, values between 0.3 and 0.4 indicate optimum biogas production. Values $<0.3$ or $>0.4$ suggest low substrate input or overloading conditions, respectively.

From the beginning of the inoculum acclimation time and up to 70 days, the solid content was $114.3 \pm 15.9 \mathrm{~g} / \mathrm{L}$. During this time, the inoculum was allowed to settle to encourage solid reduction. On day 70, the PVC/PTFE reactor was inoculated with new inoculum mixture (sieved in $2 \mathrm{~mm}$ ), re-inoculated with small amount $(2 \mathrm{~L})$ of each fresh inoculum sources and diluted with water to $40 \mathrm{~L}$. Following these steps, the solid content decreased to $59 \mathrm{~g} / \mathrm{L}$, which is within the value suggested by VDI 4630 (2006) protocols. The solids concentration kept decreasing continuously over time reaching $30 \mathrm{~g} / \mathrm{L}$ on day 365 . The rationale behind the maintenance of a VS/TS $>50 \%$ and a VFA/ALK $<0.3$ was based on targeting TS $>35 \mathrm{~g} / \mathrm{L}$ which can contribute to reach steady-state conditions more rapidly.

According to data presented in Fig. 2b, variations in $\mathrm{pH}$ over time were negligible $(7.90 \pm 0.46)$. Similarly, VFA/ALK did not vary noticeable $\left(0.16 \pm 0.04 \mathrm{~g}_{\text {Acetic Acid }} / \mathrm{g}_{\mathrm{CaCO}_{3}}\right)$, except on day 827 where this ratio reached $0.31 \pm 0.02 \mathrm{~g}_{\text {Acetic Acid }} / \mathrm{g}_{\mathrm{CaCO}_{3}}$, due to addition of inoculum A that contained high VS $\left(0.69 \pm 0.05 \mathrm{~g}_{\text {Acetic Acid }} / \mathrm{g}_{\mathrm{CaCO}_{3}}\right)$. Nonetheless, VFA/ALK was rapidly adjusted to $<0.2$ after a few days of acclimation. The constant $\mathrm{pH}$ and relatively low VFA/ALK observed in the reactor indicated inoculum steadiness, which is crucial for the consistency of BMP assays.


Fig. 2. Variations in solid distribution (a) and pH, VFA/ALK (b) over time in the inoculum.

Fig. 3 shows the results obtained from the acclimated inoculum on the biodegradability of microcrystalline cellulose standard sample and its conversion to specific biogas and methane. Biogas yield was above $80 \%\left(600 \mathrm{~mL}_{\mathrm{N}} / \mathrm{g}_{\mathrm{vs}}\right)$ of the minimum required for satisfactory inoculum activity according to BMP protocols (VDI, 2006).

After only 10 days of acclimation, the best results were achieved with inoculum previously filtered (best homogeneity in comparison to the in natura inoculum) (Assays 1 to 3; Fig. 3). Although the use of dilution strategy had not provided satisfactory results $\left(\mathrm{BMP}<600 \mathrm{~mL}_{\mathrm{N}} / \mathrm{g}_{\mathrm{vs}}\right)$, the observed reduction in the TS content was thought to benefit BMP assays. After 70 days of acclimation 


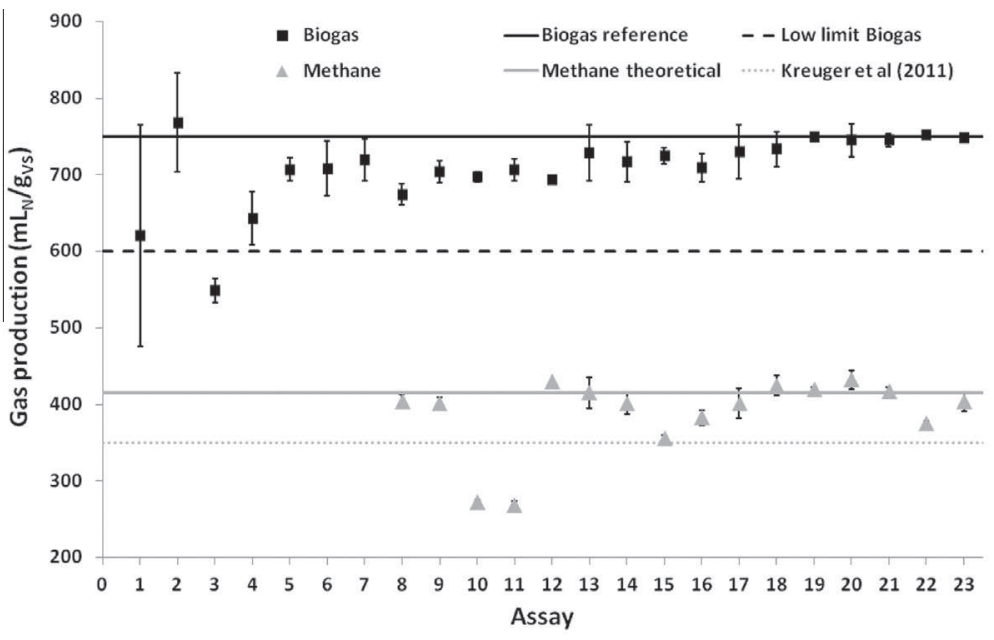

Fig. 3. Inoculum performance based on BMP tests using microcrystalline cellulose standards.

(assay 4), the performance of the inoculum was substantially increased. Satisfactory inoculum activity was indicated by the relative superior biogas yield as per VDI 4630 (2006) recommendations, i.e., $>600 \mathrm{~mL}_{\mathrm{N}} / \mathrm{g}_{\mathrm{vs}}$. Above $99 \%$ of biogas was recovered in assays 19 to 23. It was possible to note that reducing the stock culture re-inoculation cycle from 45 to 30 days had negligible effect on BMP. Thus, reduction in inoculum reactor volume $\left(\mathrm{dV}_{\text {inoculum }}=15-6 \% \mathrm{v} / \mathrm{v}\right)$ and associated acclimation time did not affect cellulose degradation efficiency.

Fig. 3 shows methane yield. The theoretical methane potential $\left(\mathrm{BMP}_{0}\right.$ ) of $415 \mathrm{~mL}_{\mathrm{N}} \mathrm{CH}_{4} / \mathrm{g}_{\mathrm{vs}}$ (Buswell and Neave, 1930) is shown in the figure. Although lower than theoretical, methane yields from cellulose (394 $\pm 18 \mathrm{~mL}_{\mathrm{N}} \mathrm{CH}_{4} / \mathrm{g}_{\mathrm{vS}}$ ) were within the expected values (350 $\mathrm{mL}_{\mathrm{N}} \mathrm{CH}_{4} / \mathrm{g}_{\mathrm{vs}}$ ) as determined by Kreuger et al. (2011) and Wang et al. (2014). The only exception was observed for assays 10 and 11 , due to problems in the gas analyzer calibration.

Table 3 show the concentrations of three major methanogenic members in inoculum from sources A, B and $\mathrm{C}$ as well as from the enrichment culture reactor collected on days 206 and 421 . Members of Methanobacteriales (MBT) and Methanomicrobiales (MMB) are generally strictly hydrogenotrophic using $\mathrm{H}_{2}$, formate, $\mathrm{CO}$, or secondary alcohols to reduce $\mathrm{CO}_{2}$ to $\mathrm{CH}_{4}$. Members of Methanosarcinales (MSL) are metabolically versatile capable to produce methane from acetoclastic, hydrogenotrophic or methylotrophic metabolism. The inoculum from source A revealed predominance of MBT and MSL. The inoculum from source B showed the lowest concentration of ARC. The high MBT gene copy numbers in this sample suggests dominance of hydrogenotrophic metabolism. This corroborates with the measured low activity for acetate (acetoclastic methanogenesis). Prevalence of MBT was not surprising considering this organisms hydrogenotrophic metabolic capacity and the presence of $\mathrm{H}_{2}$-transfer cellulolytic bacteria that are likely to thrive in fermentative process of bovine manure (Amon et al., 2007; Wang et al., 2014).

The inoculum $C$ had the highest concentrations of Archaea and MSL. The highest concentration of MSL (only acetoclastic organism known) associated with the superior methanogenic activity of acetate indicates acetoclastic metabolism was predominant. According to Angelidaki et al. (2009) for BMP test the inoculum should have a minimum activity on acetate of $0.1 \mathrm{~g} \mathrm{CH}_{4}$-COD/ (g VSS.d) for sludge and $0.3 \mathrm{~g} \mathrm{CH}_{4}$-COD/(g VSS.d) for granular sludge. However, the cellulose activity was superior for the inoculant acclimated in the reactor PVC/PTFE [0.047 $\mathrm{CH}_{4}-\mathrm{COD} /(\mathrm{g}$ VSS.d $\left.)\right]$ than for the inoculum $\mathrm{C}$ [0.014-0.020 $\mathrm{CH}_{4}-\mathrm{COD} /(\mathrm{g}$ VSS.d)]. This suggests that, even considering the high abundance of acetoclastic methanogens (MSL) present in the inoculum C, hydrolysis may still be limiting to anaerobic digestion of cellulose. Additionally, after 6-9 months storage (time between collection of fresh inoculum) the metanogenic activity of inoculum $\mathrm{C}$ declined to 0.176 $\mathrm{CH}_{4}-\mathrm{COD} /\left(\mathrm{g}\right.$ VSS.d) for acetate and $0.014 \mathrm{CH}_{4}-\mathrm{COD} /(\mathrm{g}$ VSS.d) for cellulose.

In the acclimated enriched inoculum consortium, MBT increased from $3.5 \times 10^{10}$ to $7.7 \times 10^{10}$, MMB increased from $5.0 \times 10^{9}$ to $7.7 \times 10^{10}$ and MSL increased from $4.1 \times 10^{9}$ to $4.2 \times 10^{11}$ gene copies/g. It is worth mentioning that acclimation increased overall methanogens populations as compared to each individual inoculum sources, suggesting that the method aids development of an inoculum with a wide broad metabolic activity potential. According Bauer et al. (2008), the biocenoses and the bioconversion pathways involving hydrogenotrophic and acetoclastic routes in energy crops digestion is an important factor to optimize the efficiency in the digester. In the anaerobic digestion of maize silage Bauer et al. (2008) found direct correlation between the increase in MMB with methane production. This could explain the increment in biogas yield from the cellulose standards measured in sequential assays (Fig. 3).

Williams et al. (2013) found a proportion of ARC between $2.2 \times 10^{10}$ and $1.4 \times 10^{11}$ gene copies/g in anaerobic inoculum from a full-scale digester. The digester was inoculated with sludge from a wastewater treatment plant and fed with food waste under mesophilic conditions. The same authors reported best reactor's performance in biogas production when the Methanosaetaceae (family of MSL) was the dominant methanogen member $\left(7.4 \times 10^{8}\right.$ gene copies/g). The increase in MSL was accompanied by a drop in acetoclastic microorganisms and an increase the VFA/ALK. In this work, the VFA/ALK was relatively low and stable (Fig. 2b), which may have contributed to the growth of MSL over time.

Similar results were reported by De Vrieze et al. (2015) where four different inoculum sources (i.e. sludge from brewery wastewater, organic biological waste, animal manure and energy crops anaerobic digesters) were individually tested and compared for its efficiency in BMP. Superior anaerobic digestion efficiency was observed using granular sludge from brewery industry and sludge from energy crops digester. In all these cases De Vrieze et al. (2015) found both Methanosaetaceae (MBT and MMB) in concentration between $10^{6}$ and $10^{8}$ gene copies/g in the inoculum samples. The authors report that Methanosaetaceae become dominant over time during BMP batch tests.

Table 4 summarizes the results obtained from the BMP assays in comparison to BMP data available from independent referenced 
Table 4

BMP data obtained from independent interlaboratories.

\begin{tabular}{|c|c|c|c|c|c|c|c|c|}
\hline \multirow[t]{3}{*}{ Substrate } & \multicolumn{4}{|l|}{ Reference $^{*}$} & \multicolumn{4}{|l|}{ This study } \\
\hline & \multicolumn{2}{|c|}{ Biogas yield (NmL/gVS) } & \multicolumn{2}{|c|}{$\mathrm{BMP}\left(\mathrm{NmL}_{\mathrm{CH}_{4}} / \mathrm{gVS}\right)$} & \multicolumn{2}{|c|}{ Biogas yield (NmL/gVS) } & \multicolumn{2}{|c|}{$\mathrm{BMP}\left(\mathrm{NmL}_{\mathrm{CH}_{4}} / \mathrm{gVS}\right)$} \\
\hline & $\operatorname{Mean}^{\mathrm{a}}(\mathrm{SD})$ & $\mathrm{n}$ & $\operatorname{Mean}^{\mathrm{a}}(\mathrm{SD})$ & $\mathrm{n}$ & Mean (SD) & $\mathrm{n}$ & Mean (SD) & $\mathrm{n}$ \\
\hline Cellulose & $719(99)^{A}$ & 22 & $316(75)^{X}$ & 33 & $725(2)^{A}$ & 3 & $341(13)^{X}$ & 3 \\
\hline Gelatin & $621(154)^{\mathrm{A}, \mathrm{B}}$ & 15 & $361(162)^{\mathrm{X}}$ & 18 & $583(37)^{\mathrm{B}}$ & 3 & $366(6)^{x}$ & 3 \\
\hline Poultry litter & $248(117)^{\mathrm{D}}$ & 22 & $135(33)^{\mathrm{Z}}$ & 34 & $265(16)^{\mathrm{D}}$ & 3 & $164(10)^{\mathrm{Z}}$ & 3 \\
\hline Dried sludge & $405(155)^{\mathrm{B}, \mathrm{C}, \mathrm{D}}$ & 17 & $187(62)^{Y, Z}$ & 21 & $408(8)^{C}$ & 3 & $184(3)^{\mathrm{Y}}$ & 3 \\
\hline
\end{tabular}

Reference values obtained from anaerobic digestion interlaboratory studies (Steinmetz et al., 2015); SD = standard deviation; $\mathrm{n}=$ sample size; similar letters indicate insignificant difference according to ANOVA (at $p<0.05$ ).

a Robust mean.

laboratories (Study Report DOC 175 according Steinmetz et al., 2015). Substrate samples of microcrystalline cellulose, gelatin, poultry litter and dried sludge from wastewater were utilized as substrates during the tests using identical initial concentrations. These substrates were preferred in attempt to best characterize typical feedstocks encountered for biogas production at field scale. Therefore, cellulose which contains high carbohydrates content was expected to characterize the high carbon and energy contents from crops or wood-based substrates (e.g. wastes from wood processing or wide-ranging agricultural residues). Gelatin consists of a substrate with high protein content which best mimic wastes containing high nitrogen concentrations (e.g. animal manure, food and slaughterhouse wastes). Poultry litter and dried sludge from wastewater samples are composed by different sources of organic compounds with broad characteristics. The results obtained for specific biogas yield and BMP were not statistically different $(p<0.05)$ from the referenced data. Despite the statistically similarity observed among data, it is noteworthy mentioning that averages obtained in this study were noticeably higher than average. Similarly, the comparatively higher standard deviations observed in the data from referenced laboratories suggests that variations in inoculum enrichment and acclimation used by these laboratories most likely interfere with efficient biogas production. Therefore, the results provide evidences to support that the proposed enrichment and acclimation method presented here was efficient to perform accurate and consistent BMP assays from a wide range of substrates feedstock.

\section{Conclusion}

An alternative method for developing and maintain an inoculum for BMP assay was demonstrated. The anaerobic enrichment culture showed consistent $\mathrm{pH}$ and VFA/ALK values over time and contributed to biogas production $>600 \mathrm{~mL}_{\mathrm{N}} / \mathrm{g}_{\mathrm{Vs}}$ which is above $80 \%$ as suggested by VDI 4630 protocols. The anaerobic enrichment revealed a broad methanogenic capability potential with dominance of Methanosarcinales. The proposed enrichment and acclimation method can efficiently and reliably predict biogas yield from a wide range of substrates and it represents an alternative strategy for laboratories encountered in locations lacking mesophilic upscale digesters.

\section{Acknowledgements}

This work was financially supported by the BiogásFert Network (Project $\mathrm{N}^{\circ}$ 021280400-02) and featured contributions from the Rede de Avaliação de Substratos (RAS - supported by the PROBIOGAS Project and the Deutsche Gesellschaft für Internationale Zusammenarbeit). The authors thank Ms. Taís C. Gaspareto for her assistance in the laboratory analyses.

\section{References}

Amon, T., Amon, B., Kryvoruchko, V., Zollitsch, W., Mayer, K., Gruber, L., 2007. Biogas production from maize and dairy cattle manure - influence of biomass composition on the methane yield. Agric. Ecosyst. Environ. 118, 173-182. http://dx.doi.org/10.1016/j.agee.2006.05.007.

Angelidaki, I., Alves, M., Bolzonella, D., Borzacconi, L., Campos, J.L., Guwy, A.J., Kalyuzhnyi, S., Jenicek, P., van Lier, J.B., 2009. Defining the biomethane potential (BMP) of solid organic wastes and energy crops: a proposed protocol for batch assays. Water Sci. Technol. 59, 927. http://dx.doi.org/10.2166/wst.2009.040.

APHA, Awwa, WEF, 2012. Standard Methods for Evaluation of Water and Wastewater, 22nd ed. American Public Health Association, American Water Works Association, Water Environment Federation.

ASTM International, 2001. ASTM E2170-01 Standard Test Method for Determining Anaerobic Biodegradation Potential of Organic Chemicals under Methanogenic Conditions. http://dx.doi.org/10.1520/E2170-01R08.2.

Bauer, C., Korthals, M., Gronauer, A., Lebuhn, M., 2008. Methanogens in biogas production from renewable resources - a novel molecular population analysis approach. Water Sci. Technol. 58, 1433-1439. http://dx.doi.org/10.2166/ wst.2008.514.

Buchauer, K., 1998. A comparison of two simple titration procedures to determine volatile fatty acids in influents to waste-water and sludge treatment processes. Water SA 24, 49-56.

Buswell, A.M., Neave, S.L., 1930. Bulletin No. 30 - Laboratory Studies of Sludge Digestion, first ed. Jeffersons Printing \& Stationery Co, Springfield, Illinois, USA.

Chen, Y., Cheng, J.J., Creamer, K.S., 2008. Inhibition of anaerobic digestion process: a review. Bioresour. Technol. 99, 4044-4064. http://dx.doi.org/10.1016/j. biortech.2007.01.057.

De Vrieze, J., Raport, L., Willems, B., Verbrugge, S., Volcke, E., Meers, E., Angenent, L. T., Boon, N., 2015. Inoculum selection influences the biochemical methane potential of agro-industrial substrates. Microb. Biotechnol. 8, 776-786. http:// dx.doi.org/10.1111/1751-7915.12268.

Deublein, D., Steinhauser, A., 2010. Biogas from Waste and Renewable Resources: An Introduction.

Deutsches Institut für Normung (DIN), 1985. DIN 384140-8 German Standard Method for the Examination of Water, Waste Water and Sludge. Sludge and Sediment (group S). Determination of Amenability to anaerobic digestion (S8).

Gu, Y., Chen, X., Liu, Z., Zhou, X., Zhang, Y., 2014. Effect of inoculum sources on the anaerobic digestion of rice straw. Bioresour. Technol. 158, 149-155. http://dx. doi.org/10.1016/j.biortech.2014.02.011.

Hussain, A., Dubey, S.K., 2015. Specific methanogenic activity test for anaerobic degradation of influents. Appl. Water Sci. http://dx.doi.org/10.1007/s13201015-0305-z.

International Organization for Standardization, 1995. ISO 11734 -Water Quality Evaluation of "Ultimate" Anaerobic Biodegradability of Organic Compounds in Digested Sludge - Method by Measurement of Biogas Production.

Kreuger, E., Sipos, B., Zacchi, G., Svensson, S.-E., Björnsson, L., 2011. Bioconversion of industrial hemp to ethanol and methane: the benefits of steam pretreatment and co-production. Bioresour. Technol. 102, 3457-3465. http://dx.doi.org/ 10.1016/j.biortech.2010.10.126.

Kunz, A., Miele, M., Steinmetz, R.L.R., 2009. Advanced swine manure treatment and utilization in Brazil. Bioresour. Technol. 100, 5485-5489.

Labatut, R.A., Angenent, L.T., Scott, N.R., 2011. Biochemical methane potential and biodegradability of complex organic substrates. Bioresour. Technol. 102, 22552264. http://dx.doi.org/10.1016/j.biortech.2010.10.035.

Li, J., Zicari, S.M., Cui, Z., Zhang, R., 2014. Processing anaerobic sludge for extended storage as anaerobic digester inoculum. Bioresour. Technol. 166, 201-210. http://dx.doi.org/10.1016/j.biortech.2014.05.006.

Lili, M., Biró, G., Sulyok, E., Petis, M., Borbély, J., Tamás, J., 2011. Novel approach on the basis of FOS/TAC method. Risk Factors Environ. Food Saf, 713-718

Mezzari, M.P., da Silva, M.L.B., Nicoloso, R.S., Ibelli, A.M.G., Bortoli, M., Viancelli, A., Soares, H.M., 2013. Assessment of $\mathrm{N}_{2} \mathrm{O}$ emission from a photobioreactor treating ammonia-rich swine wastewater digestate. Bioresour. Technol. 149, 327-332. http://dx.doi.org/10.1016/j.biortech.2013.09.065.

Reitschuler, C., Lins, P., Illmer, P., 2014. Primer evaluation and adaption for costefficient SYBR green-based qPCR and its applicability for specific quantification 
of methanogens. World J. Microbiol. Biotechnol. 30, 293-304. http://dx.doi.org/ 10.1007/s11274-013-1450-x.

Song, M., Shin, S.G., Hwang, S., 2010. Methanogenic population dynamics assessed by real-time quantitative PCR in sludge granule in upflow anaerobic sludge blanket treating swine wastewater. Bioresour. Technol. 101, S23-S28. http://dx. doi.org/10.1016/j.biortech.2009.03.054.

Steinmetz, R.L.R., Kunz, A., Amaral, A.C., do Soares, H.M., Schmidt, T., Wedwitschka, H., 2014. Suggested method for mesophilic inoculum acclimation to BMP assay. In: IWA (Ed.), XI Simposio Latinoamericano de Digestión Anaeróbia. La Habana, Cuba, pp. 1-8.

Steinmetz, R.L.R., Kunz, A., do Amaral, A.C. Tápparo, D.C. Correa, J.C., Gaspareto, T.C., Soares, H.M., 2015. DOC 175 - Interlaboratory Study in Anaerobic
Digestion: Activities and Laboratories Performance Report in 2014. Concórdia/ Brasil.

VDI, 2006. VDI 4630 - Fermentation of Organic Materials Characterisation of the Substrate, Sampling, Collection of Material Data, Fermentation Tests.

Wang, B., Nges, I.A., Nistor, M., Liu, J., 2014. Determination of methane yield of cellulose using different experimental setups. Water Sci. Technol. 70, 599. http://dx.doi.org/10.2166/wst.2014.275.

Williams, J., Williams, H., Dinsdale, R., Guwy, A., Esteves, S., 2013. Monitoring methanogenic population dynamics in a full-scale anaerobic digester to facilitate operational management. Bioresour. Technol. 140, 234-242. http:/ dx.doi.org/10.1016/j.biortech.2013.04.089. 